\title{
Recurrent Soft Tissue Sarcoma
}

National Cancer Institute

\section{Source}

National Cancer Institute. Recurrent Soft Tissue Sarcoma. NCI Thesaurus. Code

C139002.

The reemergence of soft tissue sarcoma after a period of remission. 